\title{
MAGEB18 Gene
}

National Cancer Institute

\section{Source}

National Cancer Institute. MAGEB18 Gene. NCI Thesaurus. Code C104521.

This gene may enhance ubiquitin ligase activity. 